\title{
Changes in digestive enzymes activities during the initial ontogeny of wolf cichlid, Parachromis dovii (Perciformes: Cichlidae)
}

\author{
Carlos Alfonso Frías-Quintana ${ }^{1}$, Carlos Alfonso Álvarez-González², \\ Rocío Guerrero-Zárate ${ }^{2}$, Silvia Valverde-Chavarría ${ }^{3}$ and Juan B. Ulloa-Rojas ${ }^{3}$
}

Wolf cichlid, Parachromis dovii, is a species with a high potential for aquaculture in Central America; however, the knowledge of the digestive physiology in larvae period is limited. For these reason, this study evaluated the changes on digestive enzymes (alkaline and acid proteases, trypsin, chymotrypsin, aminopeptidase, carboxypeptidase, lipases, amylases, and phosphatases) during early ontogeny by biochemical analysis. All digestive enzymes were detected at first feeding (6 days after hatching, DAH, $9.49 \mathrm{~mm}, 168$ degree-days DD). Afterwards all enzymes reached two main peaks in activity at 14 or 22 DAH $(15.10 \mathrm{~mm}, 364 \mathrm{DD}$ and $20.83 \mathrm{~mm}, 550 \mathrm{DD}$, respectively). Later, there was a gradual decrease in activity for trypsin and acid and alkaline phosphatases until reach the lowest values at $41 \mathrm{DAH}$. In the case of acid proteases, chymotrypsin, aminopeptidase, carboxypeptidase, lipase and amylase, all activities reached their maximum values at the end of the larval period, except for alkaline proteases, which showed the maximum value at $14 \mathrm{DAH}(15.10 \mathrm{~mm}, 364 \mathrm{DD})$. Parachromis dovii larvae have an early capability to hydrolyze exogenous food, agreeing with other carnivorous neotropical cichlid species, for this reason we proposed that the weaning process could begin at $14 \mathrm{DAH}$.

Keywords: Larviculture, Proteases, Zymogram.

El guapote lagunero (Parachromis dovii) es una especie con un alto potencial para la acuicultura en la región de América Central; sin embargo, existe un conocimiento limitado sobre la capacidad digestiva en el periodo larval. Por este motivo, este estudio evaluó los cambios de las enzimas digestivas (proteasas alcalinas y ácidas, tripsina, quimotripsina, aminopeptidasa, carboxipeptidasa, lipasas, amilasas y fosfatasas) durante la ontogenia temprana mediante análisis bioquímico. Todas las enzimas digestivas analizadas se detectaron en la primera alimentación (6 días después de la eclosión, DAH, 9.49 mm, 168 día-grados DD). Después, todas las enzimas alcanzaron dos picos máximos a los 14 o 22 DAH (15.10 mm, 364 DD and 20.83 $\mathrm{mm}, 550 \mathrm{DD}$, respectivamente). Después las actividades tripsina, fosfatasas ácidas y alcalina disminuyeron a sus valores más bajos a los $41 \mathrm{DAH}$. En el caso de las proteasas ácidas y alcalinas, quimotripsina, aminopeptidasa, carboxipeptidasa, lipasa y amilasa, los niveles de actividad aumentaron y alcanzaron su máximo valor al final del período larvario, excepto las proteasas alcalinas, que mostraron su máximo valor a los $14 \mathrm{DAH}(15.10 \mathrm{~mm}, 364 \mathrm{DD})$. Las larvas de $P$. dovii tienen una capacidad temprana para hidrolizar alimentos exógenos, lo que concuerda con otras especies de cíclidos neotropicales carnívoros, por lo que proponemos que el proceso de destete inicie a los $14 \mathrm{DAH}$.

Palavras-clave: Larvicultura, Proteasas, Zimograma.

\section{Introduction}

The Cichlidae family is composed of about 1,000 species and is widely distributed around the tropics. It has showed a remarkable commercial importance for fisheries, sport fishing and aquaculture (Luna-Figueroa, Figueroa-Torres, 2000). In Costa Rica and in most Central America countries, one of the most important species is the Wolf cichlid, guapote lagunero (Parachromis dovii Günther, 1864), which has a tasty flesh, good performance in earthen pond culture systems and in addition, it is used as biological control for undesired reproduction in tilapia culture (Nonell, Rojas, 1995; Hernández, 1992; Barrera, Paz, 2006). However, this species still has some production problems (e.g. low growth rate) related to malnutrition especially at early stages; which had affected negatively its production at commercial scale.

${ }^{1}$ División Académica Multidisciplinaria de Jalpa de Méndez, Universidad Juárez Autónoma de Tabasco, Carretera Nacajuca-Jalpa de Méndez R/a Rivera Alta, 86200, Jalpa de Méndez, TB, Mexico. cafq22@hotmail.com, Dhttps://orcid.org/0000-0002-5407-4991

${ }^{2}$ Laboratorio de Acuacultura (DACBIOL), Universidad Juárez Autónoma de Tabasco, Carretera Villahermosa-Cárdenas Km 0.5, 86139, Villahermosa, TB, Mexico. (CAA-G) alvarez_alfonso@hotmail.com, (Dhttps://orcid.org/0000-0001-9240-0041 (corresponding author), (RG-Z) rocio7224@hotmail.com, (Ohttps://orcid.org/0000-0002-0346-0841

${ }^{3}$ Escuela de Ciencias Biológicas, Universidad Nacional, Campus Omar Dengo, Heredia 186-3000, Costa Rica. (SV-C) silvia.valverde. chavarria@una.cr, Dhttps://orcid.org/0000-0003-2823-459X,(JBU-R) juan.ulloa.rojas@una.cr, Đhttps://orcid.org/0000-0003-4464-1136 
For this reason, the knowledge of its digestive physiology is essential for maximizing its growth by knowing the fish capability to metabolize protein sources needed for tissue synthesis (Kolkovski, 2001). Further, studies on the digestive system development and enzymatic capacity should bring information to understand the nutritional status, the digestive enzyme activity and related processes to generate better strategies for control and improvement of survival at the earlier stages (larvae) (Moyano, 2006; Zambonino-Infante, Cahu, 2007).

In the past, several studies characterizing some digestive enzymes has been done with cichlids of commercial importance; Nile tilapia, Oreochromis niloticus (Linnaeus) (Tengjaroenkul et al., 2002), blue disc, Symphysodon aequifasciatus (Pellegrin) (Chong et al., 2002), Mayan cichlid, Mayaheros urophthalmus (Günther) (López-Ramírez et al., 2011), bay snook, Petenia splendida (Günther) (Uscanga-Martínez et al., 2011), three-spot cichlid, Amphilophus trimaculatus (Günther) (Toledo-Solís et al., 2015), and other fish species such as sobaity sea bream, Sparidentex hasta (Valenciennes) (Nazemroaya et al., 2015), zebrafish, Danio rerio (Hamilton) (Guerrera et al., 2015), Caspian kutum, Rutilus kutum (Kamensky) (Khosravi Bakhtiarvandi, Abedian-Kenari, 2015), golden pompano, Trachinotus ovatus (Linnaeus) (Ma et al., 2015), thick-lipped grey mullet, orange-spotted grouper, Epinephelus coioides (Hamilton) (Guo et al., 2016), starry flounder, Platichthys stellatus (Pallas) (Song et al., 2016), Chelon labrosus (Risso) (Pujante et al., 2017), turbot, Scophthalmus maximus (Linnaeus) (Tong et al., 2017), crimson snapper, Lutjanus erythropterus (Bloch) (Cui et al., 2017), American shad, Alosa sapidissima (Wilson) (Xiao-Qiang et al., 2017), clown knifefishChitala chitala (Hamilton) (Mitra et al., 2017), and barbel chub, Squaliobarbus curriculus (Richardson) (Shen et al., 2018).

These studies have allowed the understanding of digestive enzymes variability, which reflects changes in fish morpho-physiology and feed use during larvae period. Specifically, for the $P$. dovii, in Costa Rica only one study has been done related to the effect of feed on growth and proteolytic digestive activity in larvae (Quirós-Orlich et al., 2014), evaluating the live feed substitution (Artemia Leach nauplii) by an inert diet. Further, studies related to the digestive physiology of wolf cichlid are needed to improve its growth by using specific diets, before to recommend its commercial scale culture. For this reason, this research focused on the digestive proteases, lipases and amylases of $P$. dovii during early ontogeny.

\section{Material and methods}

Larvae and sampling. The larvae were obtained from broodstock of $P$. dovii (1 male: 1 female) (adult specimens are included in Ichthyological collection ROM 84151), at the hatchery unit of the Escuela de Ciencias Biológicas of Universidad Nacional de Costa Rica, maintained in fiberglass tanks with a water recirculation system by air flow. Larvae were obtained from spontaneous spawns and after hatching; all were transferred and randomly distributed into aquaria (11 L each, 23 larvae $\left.\mathrm{L}^{-1}\right)$ of a recirculation system. The water temperature was kept at $25-29^{\circ} \mathrm{C}$, dissolved oxygen at $6.0 \mathrm{~g} \mathrm{~L}^{-1}$ minimal and $\mathrm{NH}_{3}$ lower than $0.06 \mathrm{~g} \mathrm{~L}^{-1}$.

Larvae were fed to satiety with Artemia nauplii (Great Salt Lake, Artemia International $\left.{ }^{\circledR}\right)$ four times daily (9:00, 11:30, 14:30 and 17:00 $\mathrm{h}$ ) from the beginning of exogenous feeding ( 6 day after hatching, DAH) until the end of the larval period (30 DAH). The larvae were fed with a pelletized formulated feed SilverCup ${ }^{\circledR}(45 \%$ protein and $10 \%$ lipids) at the same larvae feeding frequency.After the programmed feedings, the surplus food was cleaned by suction with a hose to avoid excess nutrients and the subsequent contamination of the water.

Growth and survival. The specific growth rate (SGR) for weight and total length was calculated at the end of the trial by the formula: $\mathrm{SGR}=\left(\ln \mathrm{W}_{\mathrm{f}}-\ln \mathrm{W}_{\mathrm{i}} / \mathrm{t}_{2}-\mathrm{t}_{1}\right) * 100(\%$ body length day ${ }^{-1}$ or $\%$ body weight day $\left.{ }^{-1}\right)$, where: ln: natural logarithm, $\mathrm{W}_{\mathrm{f}}$ : final length or weight ( $\mathrm{mm}$ or $\mathrm{mg}$ ), $\mathrm{W}_{\mathrm{i}}$ : initial length or weight (mm or $\mathrm{mg}$ ), $\mathrm{t}_{2}$ : final day, $\mathrm{t}_{1}$ : initial day. Survival rates were determined by counting remaining larvae at the end of the experiment and it was corrected for number of sampled larvae.

Degree-days calculation. For the determination of the degrees-days: $\mathrm{DD}=[$ Tmax-Tmin/2]-To, where Tmax and Tmin are the maximum and minimum daily ambient temperature, respectively, and To is the temperature below which growth or development does not occur (often referred to as the base or threshold temperature, Hazel, Prosser, 1974; Sharpe, DeMichele, 1977) multiplying for the number of days after hatching (DAH).

Sampling technique. Samples of 30 larvae were randomly taken on days: $6\left(9.49 \mathrm{~mm}, 168 \mathrm{DD}, 0.056 \mathrm{~mm} .{ }^{\circ} \mathrm{C}\right.$.days $)$, 14 (15.10 mm, $364 \mathrm{DD}, 0.041 \mathrm{~mm} .{ }^{\circ} \mathrm{C}$.days $), 22(20.83 \mathrm{~mm}$, $550 \mathrm{DD}, 0.057 \mathrm{~mm} .{ }^{\circ} \mathrm{C}$.days $), 30(23.42 \mathrm{~mm}, 810 \mathrm{DD}, 0.028$ $\mathrm{mm} .{ }^{\circ} \mathrm{C}$.days $)$ and $41\left(27.66 \mathrm{~mm}, 1189 \mathrm{DD}, 0.023 \mathrm{~mm} .{ }^{\circ} \mathrm{C}\right.$. days) DAH and DD respectively before feeding in the morning. Larvae were anesthetized until dead with an overdose of tricaine metansulfonate (MS-222, $0.15 \mathrm{mg} \mathrm{L}^{-1}$ ), measured with a stereoscopy (Olympus 329345 with ocular micrometer: $\pm 0.07 \mathrm{~mm})$ and a caliper $( \pm 0.01 \mathrm{~mm})$, and weighted with an analytical balance (Sartorius $2492 \pm 0.1 \mathrm{mg}$ ). The growth in total length and weight was calculated as specific growth rate (SGR) and survival was monitored daily. Finally, larvae were washed with distilled water, frozen at $-20^{\circ} \mathrm{C}$ and lyophilized for further biochemical analysis.

Preparation of multi-enzymatic extracts. The viscera bulk was removed from each larva in cold conditions (kept on plates maintained in ice), by cutting off the tail, head and dorsal part of the body. Samples from the smallest larvae were taken by removing their head and tail. Viscera were split in two sections, to analyze stomach and intestine en- 
zymatic activity separately. Samples for alkaline enzymes determinations were homogenized with buffer $50 \mathrm{mmol} \mathrm{L}^{-1}$ Tris- $\mathrm{HCl}, \mathrm{CaCl}_{2} 20 \mathrm{mmol} \mathrm{L}^{-1}$, pH $7.5\left(35 \mathrm{mg} \mathrm{mL}^{-1}\right)$ and for acid enzymes determinations with buffer $100 \mathrm{mmol} \mathrm{L}^{-1}$ glycine-HCl, pH 2.0. Next, samples were centrifuged at 16000 $\mathrm{g}, 4^{\circ} \mathrm{C}$ for $30 \mathrm{~min}$ (Hettich Mikro 200). The supernatant was kept at $-20^{\circ} \mathrm{C}$ f or further enzymatic analysis.

Biochemical analysis. The soluble protein concentration was determined by Bradford (1976), using serum bovine albumin as standard. Total alkaline proteolytic activity was measured according to Walter (1984), using casein $(0.5 \%)$ as substrate in a Tris-HCl $50 \mathrm{mmol} \mathrm{L}^{-1}, \mathrm{pH} 9.0$ buffer solution. Total acid proteolytic activity was determined following Anson (1938), using hemoglobin (0.5\%) in a glycine- $\mathrm{HCl}$ $100 \mathrm{mmol} \mathrm{L}^{-1}, \mathrm{pH} 2.0$ buffer solution. One unit of enzymatic activity was defined as $1 \mu \mathrm{g}$ tyrosine released per minute, using the 0.005 molar extinction coefficient at $280 \mathrm{~nm}$.

Trypsin activity was done according to Erlanger et al. (1961), using as substrate BAPNA ( $\mathrm{N}-\alpha$-benzoyl-DL-arginine p-nitroanilide) dissolved in dimetilsulfoxide (DMSO) $10 \mathrm{mmol} \mathrm{L}^{-1}$ and Tris- $\mathrm{HCl} 50 \mathrm{mmol} \mathrm{L}^{-1}, \mathrm{CaCl}_{2} 10 \mathrm{mmol} \mathrm{L}^{-1}$, pH 8.2 buffer solution. Chymotrypsin activity was measured following Del Mar et al. (1979), with SAAPNA (N-succinyl-ala-ala-pro-phe p-nitroanilide) as specific substrate dissolved in DMSO $10 \mathrm{mmol} \mathrm{L}^{-1}$ and Tris- $\mathrm{HCl} 100 \mathrm{mmol}$ $\mathrm{L}^{-1}, 1 \mathrm{mmol} \mathrm{L}^{-1} \mathrm{CaCl}_{2}, \mathrm{pH} 7.8$ buffer solution. The activity of leucine-aminopeptidase was evaluated with the protocol of Maroux et al. (1973), using leucine $p$-nitroanilide $(0.1 \mathrm{mmol}$ $\mathrm{L}^{-1}$ dissolved in DMSO) as substrate and a sodium phosphate $50 \mathrm{mmol} \mathrm{L}^{-1}, \mathrm{pH} 7.2$ buffer solution. For these proteases, one unit of enzymatic activity was defined as $1 \mu \mathrm{g}$ of nitroanilide released per minute; using the following molar extinction coefficients: 8.8 for trypsin at $410 \mathrm{~nm}, 0.962$ for chymotrypsin at $405 \mathrm{~nm}$ and 8.2 for leucine-aminopeptidase at 410 $\mathrm{nm}$. The activity of carboxypeptidase A was evaluated according to Folk, Schirmer (1963), using hipuryl-L-phenylalanine $1 \mathrm{mmol} \mathrm{L}^{-1}$ as substrate in Tris- $\mathrm{HCl} 25 \mathrm{mmol} \mathrm{L}^{-1}, \mathrm{NaCl}$ $50 \mathrm{mmol} \mathrm{L}^{-1}, \mathrm{pH} 7.5$ buffer solution. One unit of enzymatic activity was defined as $1 \mu \mathrm{g}$ of hipuryl released per minute, using a 0.36 molar extinction coefficient at $254 \mathrm{~nm}$.

The $\alpha$-amylase analyses was realized following Somoyi-Nelson procedure (described by Robyt, Whelan, 1968) using soluble starch $(2 \%)$ as substrate in a phosphate-citrate $100 \mathrm{mmol} \mathrm{L}^{-1}, \mathrm{NaCl} 50 \mathrm{mmol} \mathrm{L}^{-1} \mathrm{pH} 7.5$ buffer solution. One unit of enzymatic activity was defined as $1 \mu \mathrm{g}$ of maltose released per minute, using a 0.0034 molar extinction coefficient at $600 \mathrm{~nm}$. Lipase activity was quantified as described by Versaw et al. (1989), using $\beta$-naphthyl caprylate (200 $\left.\mathrm{mmol} \mathrm{L}^{-1}\right)$ as substrate, Tris- $\mathrm{HCl} 50 \mathrm{mmol} \mathrm{L}^{-1} \mathrm{pH} 7.2$ buffer solution and sodium taurocholate $\left(100 \mathrm{mmol} \mathrm{L}^{-1}\right)$. A unit of enzymatic activity was defined as $1 \mu \mathrm{g}$ of naphthyl released per minute, using a 0.02 molar extinction coefficient at $540 \mathrm{~nm}$.

The acid and alkaline phosphatase activities were measured according to Bergmeyer (1974), incubating the ex- tracts for the acid and alkaline phosphatase with 4-nitrophenyl phosphate $2 \%$ in citric/citrate $(1: 1 \mathrm{~W} / \mathrm{W}) \mathrm{pH} 5.5$ and glycine- $\mathrm{NaOH} 50 \mathrm{mmol} \mathrm{L}^{-1} \mathrm{pH} 10.1$ buffer solutions, respectively. A unit of enzymatic activity was defined as $1 \mu \mathrm{g}$ of naphthyl released per minute, using a 0.0185 molar extinction coefficient at $405 \mathrm{~nm}$.

Enzyme activity was calculated, by triplicate, following this equation: Total activity (Units $\left.\mathrm{mL}^{-1}\right)=[\Delta$ abs*reaction final volume $(\mathrm{mL})] /\left[\mathrm{MEC}^{*}\right.$ time $(\mathrm{min}) *$ extract volume $(\mathrm{mL})]$. Specific activity (Units $\mathrm{mg}$ prot $\left.^{-1}\right)=$ Total activity/ soluble protein $(\mathrm{mg})$, where $\Delta$ abs represent the increase in absorbance, and MEC represents the respective molar extinction coefficient.

Zymogram analysis. The classification of proteases was obtained by SDS-PAGE electrophoresis with discontinuous gels for alkaline proteases (Laemmli, 1970; García-Carreño et al., 1993). The enzymatic extracts were mixed with the sample buffer (Tris-HCl $50 \mathrm{mmol} \mathrm{L}^{-1}, \mathrm{pH}$ 6.8, glycerol, SDS, bromophenol blue) at a $\mathrm{v} / \mathrm{v}$ ratio of $1: 1$, and $20 \mu \mathrm{L}$ of this mixture was applied on the gel wells $(8.3 \mathrm{~cm} 96.1 \mathrm{~cm} 90.75$ $\mathrm{cm})$. The discontinuous zymograms consisted of a storage gel at $4 \%$ and a separating gel at $10 \%$. The gel was equilibrated at $80 \mathrm{~V}$ for $15 \mathrm{~min}$, and the electrophoresis was done at $100 \mathrm{~V}$ and $120 \mathrm{~mA}$ for $100 \mathrm{~min}$ (Mini Protean III BIORAD Laboratories, CA, USA). The gels were submerged in a $2 \%$ casein solution in Tris- $\mathrm{HCl} 50 \mathrm{mmol} \mathrm{L}^{-1}, \mathrm{pH} 9$ at $4^{\circ} \mathrm{C}$ for 60 min to allow the gels to absorb the casein and then incubated at $37^{\circ} \mathrm{C}$ during $18 \mathrm{~h}$ to allow the substrate hydrolysis. After development of enzyme activity, gels were stained by using the same Coomassie brilliant blue R-250 solution.

Reference front (Rf) and molecular weight calculations. A low molecular weight marker (LRMWM) from Pharmacia Biotech (Uppsala, Sweden) was applied to each SDS-PAGE adding $5 \mu \mathrm{l}$ well. The LRMWM contained the following proteins: 1) phosphorylase $b(97 \mathrm{kDa}), 2)$ serum bovine albumin $(66 \mathrm{kDa}), 3)$ egg albumin $(45 \mathrm{kDa}), 4)$ carbonic anhydrase $(29 \mathrm{kDa}), 5)$ trypsinogen $(24 \mathrm{kDa})$, and 6$)$ soybean trypsin inhibitor $(20 \mathrm{kDa})$. The relative electromobility (Rf) for all zymograms was calculated according to Igbokwe, Downe (1978), and the molecular weight (MW) of each band with alkaline protease activity was calculated as the linear fit between the Rf and the decimal logarithm of the molecular weights of the proteins used as markers, using the software Quality One V 4.6.5 (Hercules, CA, USA).

\section{Results}

At first feeding, $P$. dovii larvae weighed $7.56 \pm 0.39$ $\mathrm{mg}$ and measured $9.49 \pm 0.28 \mathrm{~mm}(6 \mathrm{DAH}, 168 \mathrm{DD}, 0.056$ $\mathrm{mm} .{ }^{\circ} \mathrm{C}$.days), reaching $268.66 \pm 25.44 \mathrm{mg}$ and $27.66 \pm 1.06$ $\mathrm{mm}$ (41 DAH, $1189 \mathrm{DD}, 0.023 \mathrm{~mm} .{ }^{\circ} \mathrm{C}$.days) at the end of the study. The final SGR was $10.20 \%$ and $3.06 \%$ for wet weight and total length, respectively. The growth was exponential during larval development (Fig. 1). Survival was over $95 \%$ along experimental time. 


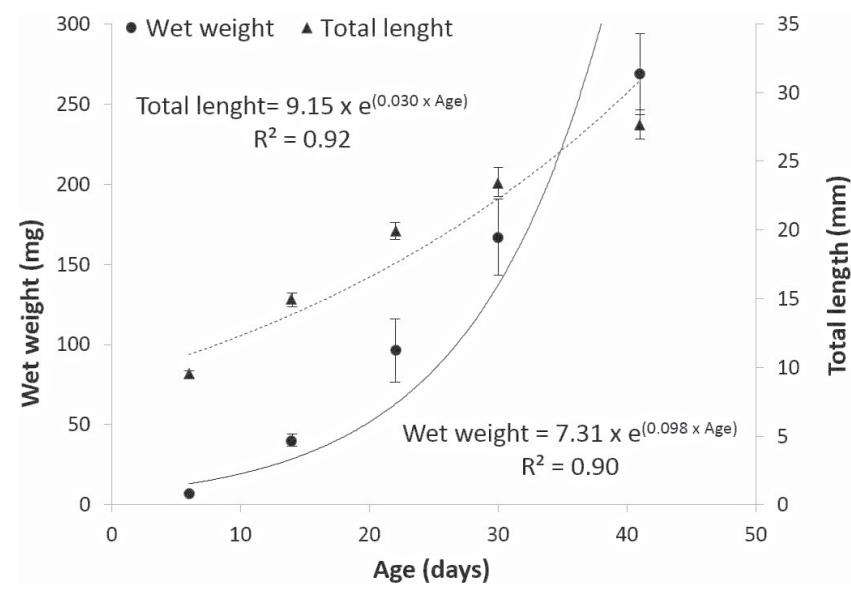

Fig. 1. Wet weight (mg) and total length (mm) of Parachromis dovii $($ mean $\pm \mathrm{SD}, \mathrm{n}=30)$ during experimental period.

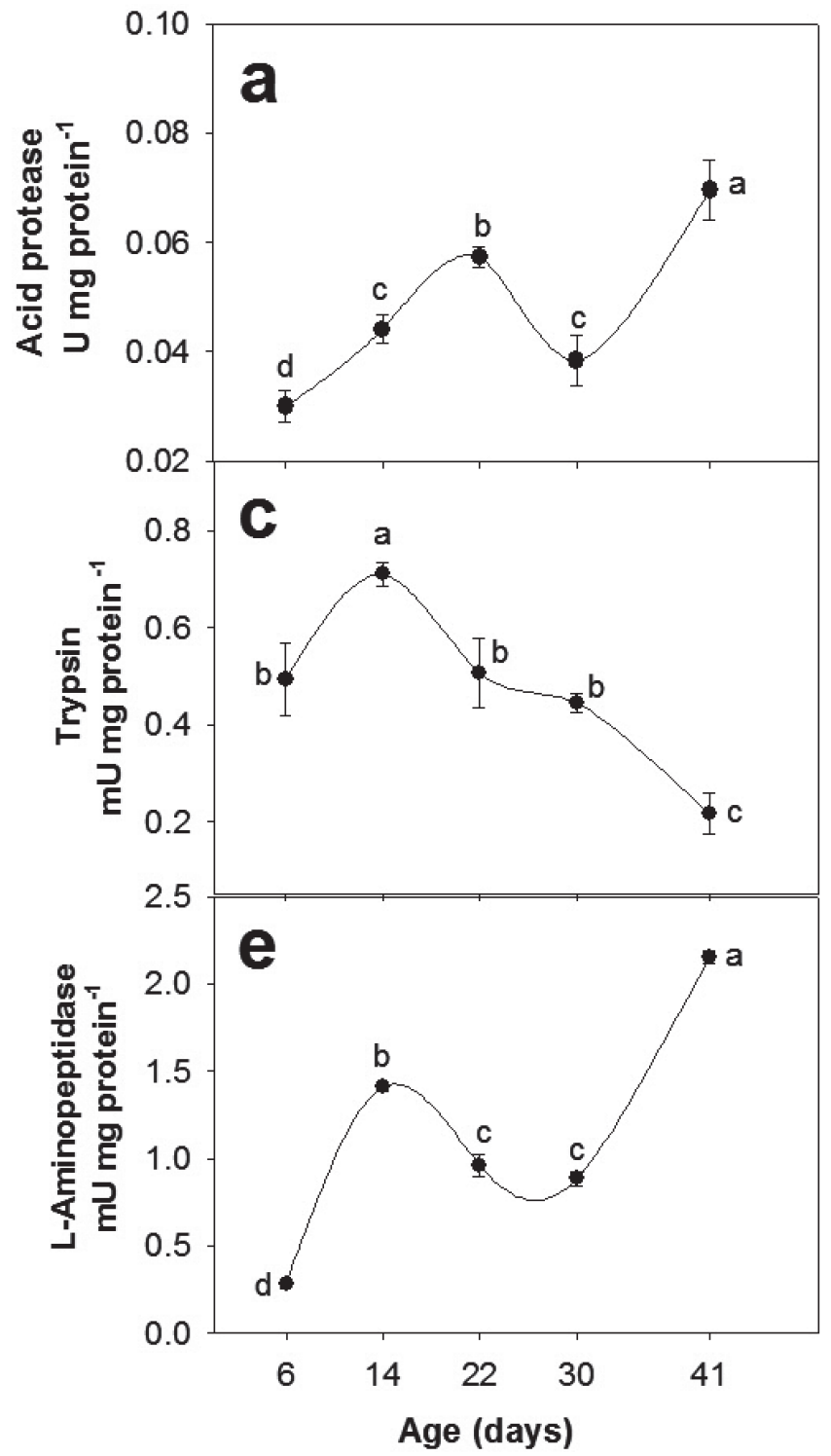

All digestive enzymes tested were detected at first feeding (6 DAH, $9.49 \mathrm{~mm}, 168 \mathrm{DD}, 0.056 \mathrm{~mm} .{ }^{\circ} \mathrm{C}$.days). The specific acid proteolytic activity reached a peak at $22 \mathrm{DAH}$ (20.83 mm, $550 \mathrm{DD}, 0.057 \mathrm{~mm} .{ }^{\circ} \mathrm{C}$.days), decreased at 30 DAH (23.42 mm, $810 \mathrm{DD}, 0.028 \mathrm{~mm} .{ }^{\circ} \mathrm{C}$.days), reaching to a maximum level at $41 \mathrm{DAH}(27.66 \mathrm{~mm}, 1189 \mathrm{DD}, 0.023$ $\mathrm{mm} .{ }^{\circ} \mathrm{C}$.days) (Fig. 2a). The specific alkaline proteolytic activity (Fig. 2b) reached the maximum level at 14 DAH (15.10 $\mathrm{mm}, 364 \mathrm{DD}, 0.041 \mathrm{~mm} .{ }^{\circ} \mathrm{C}$.days), decreased at day 22 after hatching (20.83 mm, $550 \mathrm{DD}, 0.057 \mathrm{~mm} .{ }^{\circ} \mathrm{C}$.days) and finally increased from day 30 to $41 \mathrm{DAH}(23.42 \mathrm{~mm}, 810 \mathrm{DD}$, $0.028 \mathrm{~mm} .{ }^{\circ} \mathrm{C}$.days and $27.66 \mathrm{~mm}, 1189 \mathrm{DD}, 0.023 \mathrm{~mm} .{ }^{\circ} \mathrm{C}$. days, respectively). The trypsin specific activity reached the highest level at $14 \mathrm{DAH}\left(15.10 \mathrm{~mm}, 364 \mathrm{DD}, 0.041 \mathrm{~mm} .{ }^{\circ} \mathrm{C}\right.$. days) and then, diminished gradually until $41 \mathrm{DAH}(27.66$ mm, 1189 DD, 0.023 mm. ${ }^{\circ}$ C.days) (Fig. 2c). Chymotrypsin,

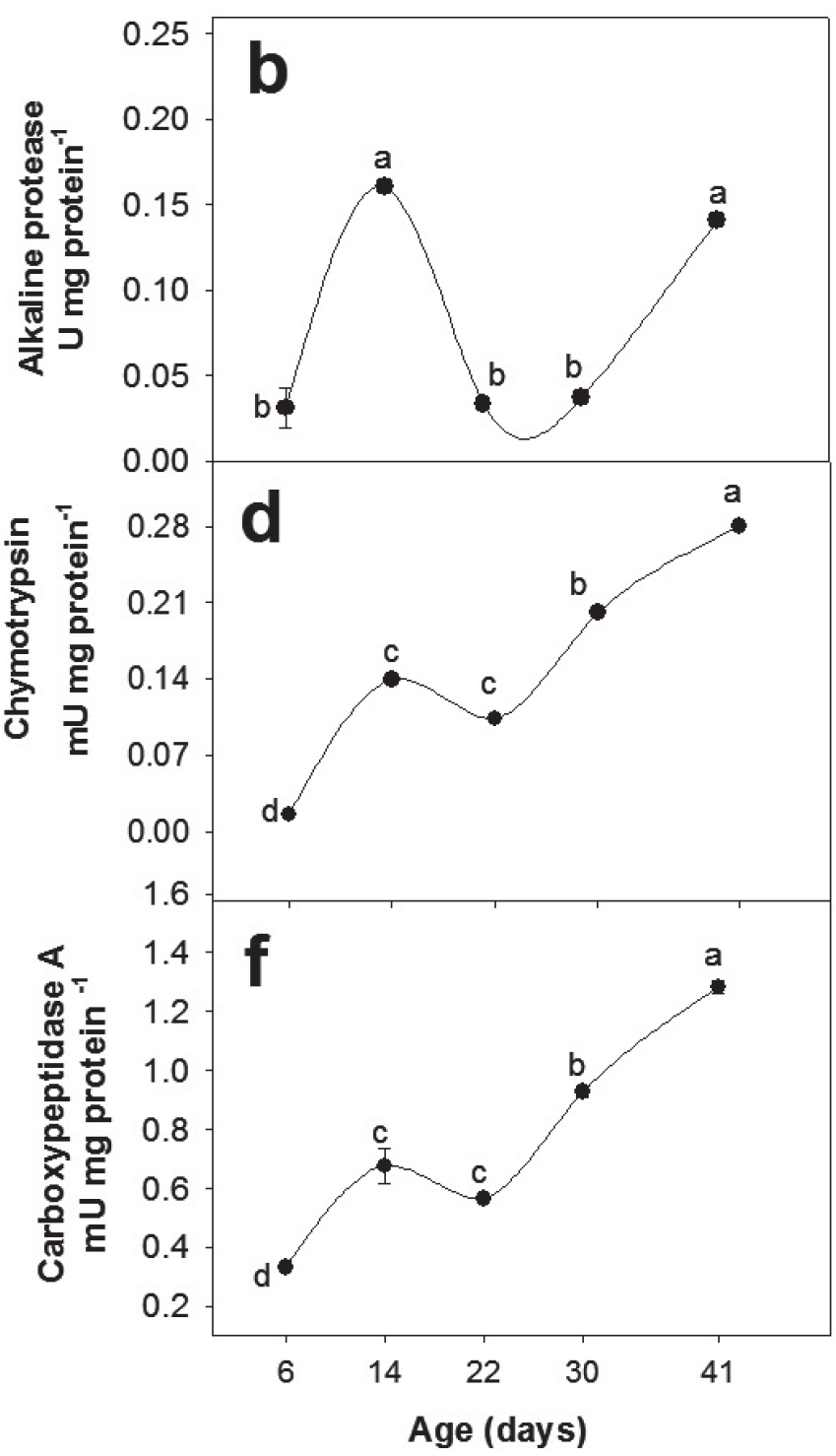

Fig. 2. Digestive proteolytic enzyme activity during ontogeny of Parachromis dovii larvae (means $\pm \mathrm{SD}, \mathrm{n}=3$ replicates). (a) specific acid proteolytic activity, (b) specific alkaline proteolytic activity, (c) specific trypsin activity, (d) specific chymotrypsin activity, (e) specific leucine-aminopeptidase activity, (f) specific carboxypeptidase A activity. 
leucine-aminopeptidase and carboxypeptidase specific activity showed a peak at $14 \mathrm{DAH}(15.10 \mathrm{~mm}, 364 \mathrm{DD}, 0.041$ $\mathrm{mm} .{ }^{\circ} \mathrm{C}$.days $)$, diminished at $22 \mathrm{DAH}(20.83 \mathrm{~mm}, 550 \mathrm{DD}$, $0.057 \mathrm{~mm} .{ }^{\circ} \mathrm{C}$.days) and reached their highest levels at 41 DAH (27.66 mm, 1189 DD, 0.023 mm. ${ }^{\circ}$ C.days) (Fig. 2d-f).

Lipase specific activity showed a peak at $14 \mathrm{DAH}$ and the highest level at $41 \mathrm{DAH}\left(27.66 \mathrm{~mm}, 1189 \mathrm{DD}, 0.023 \mathrm{~mm} .{ }^{\circ} \mathrm{C}\right.$. days) (Fig. 3a). The $\alpha$-amylase specific activity was highly fluctuating with a peak at $22 \mathrm{DAH}(20.83 \mathrm{~mm}, 550 \mathrm{DD}, 0.057$ $\mathrm{mm} .{ }^{\circ} \mathrm{C}$.days) and reaching its highest value at the end of the period (Fig. 3b). Acid phosphatase specific activity was minimal at $6 \mathrm{DAH}\left(9.49 \mathrm{~mm}, 168 \mathrm{DD}, 0.056 \mathrm{~mm} .{ }^{\circ} \mathrm{C}\right.$.days), increased at its maximal level at $14 \mathrm{DAH}(15.10 \mathrm{~mm}, 364 \mathrm{DD}$, $0.041 \mathrm{~mm} .{ }^{\circ} \mathrm{C}$.days) and then, gradually diminished until 41 DAH (Fig. 3c). Finally, alkaline phosphatase specific activity was low at 6 and $14 \mathrm{DAH}\left(9.49 \mathrm{~mm}, 168 \mathrm{DD}, 0.056 \mathrm{~mm} .{ }^{\circ} \mathrm{C}\right.$. days and $15.10 \mathrm{~mm}, 364 \mathrm{DD}, 0.041 \mathrm{~mm} .{ }^{\circ} \mathrm{C}$.days, respectively), increased to its maximum at $22 \mathrm{DAH}(20.83 \mathrm{~mm}, 550$ DD, $0.057 \mathrm{~mm} .{ }^{\circ} \mathrm{C}$.days) and then, sharply decreased until 41 DAH (27.66 mm, 1189 DD, 0.023 mm. ${ }^{\circ}$ C.days) (Fig. 3d).

The SDS-PAGE zymogram for alkaline proteases showed two bands that appeared at 6 DAH $(19.2,24.8 \mathrm{kDa})$, and a third band that was observed at $14 \mathrm{DAH}(68 \mathrm{kDa})$, three bands were present until the end of the larviculture; however, the intensity of these bands increased gradually until 41 DAH (Fig. 4).

\section{Discussion}

The growth (in weight and total length average) and survival rate of $P$. dovii larvae was higher compared to that found by Quirós-Orlich et al. (2014), who reported a SGR of $12.2 \pm 0.1 \%$ and $3.4 \pm 0.1 \%$ for weight and length, respectively, and a survival rate of $98.99 \%$ during a period of 20 days (from 8 to $28 \mathrm{DAH}$ ). In that study, P. dovii larvae were feeding with Artemia nauplii (at satiation) until 15 DAH, followed by Artemia nauplii substitution by formulated feed. The activity of digestive enzymes is used as an indicator of the larvae capability to hydrolyze nutrients and, to some extent, as a guide to elucidate the enzyme affinity to specific substrates according to feed types (Zambonino-Infante, Cahu, 2001).

Accordingly, our results show that $P$. dovii larvae had acid proteolytic activity (pepsin-like) since 6 DAH (9.49 $\mathrm{mm}, 168 \mathrm{DD}, 0.056 \mathrm{~mm} .{ }^{\circ} \mathrm{C}$.days), in agreement with the observation of a stomach with gastric glands at the time of first feeding (Valverde-Chavarría et al., 2013). This early appearance of a stomach with gastric glands has also been reported for Petenia splendida (Treviño et al., 2011). In addition, it is also possible that some of this early acid activity (6 DAH) corresponds to other acid enzymes, such as cathepsin, since the enzymatic extracts were made using the whole larvae (Moyano et al., 1996).
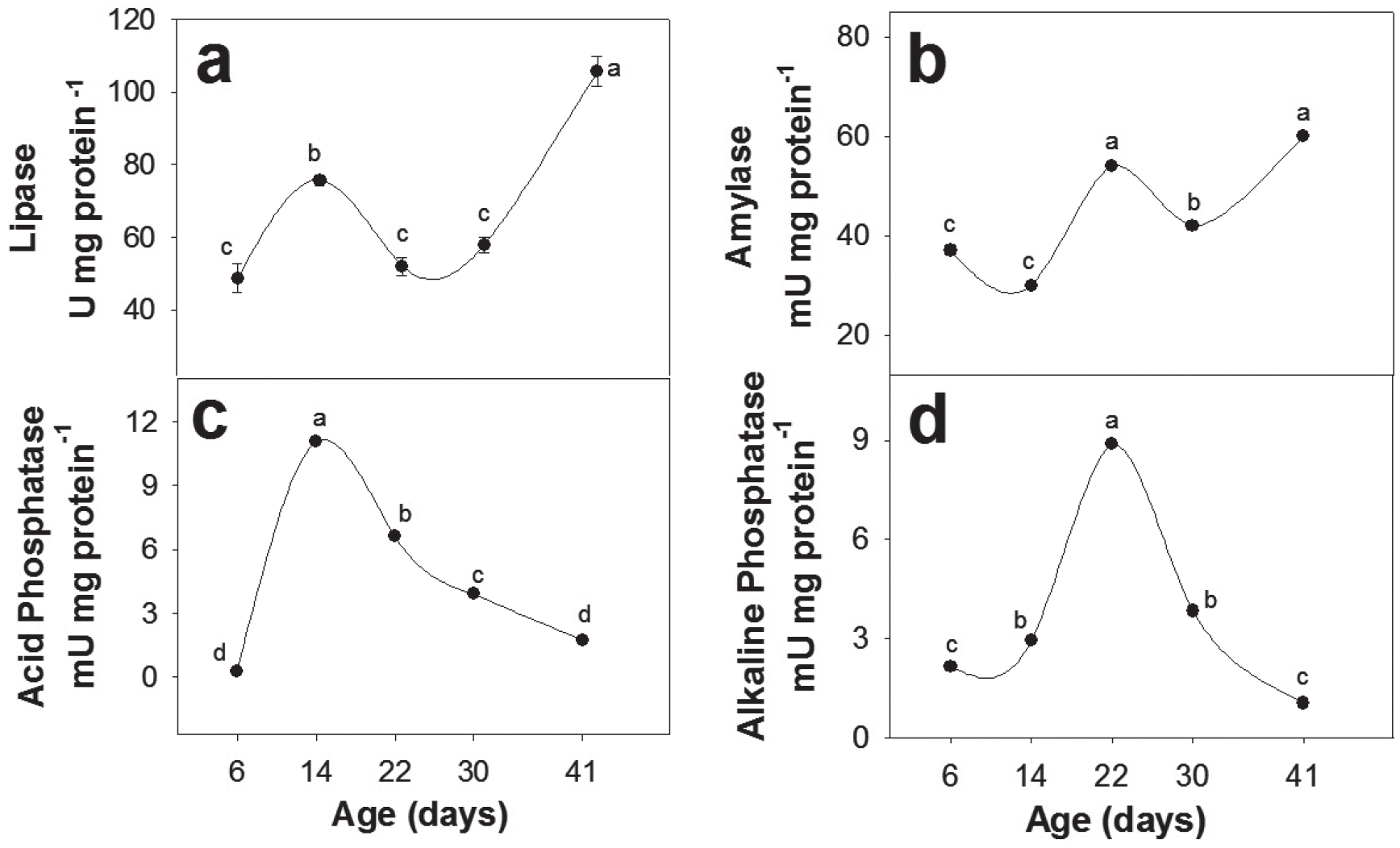

Fig. 3. Digestive enzymatic activity during ontogeny of Parachromis dovii larvae (means $\pm \mathrm{SD}, \mathrm{n}=3$ replicates). (a) specific lipase activity, (b) specific $\alpha$-amylase activity, (c) specific acid phosphatase activity, (d) specific alkaline phosphatase activity. 


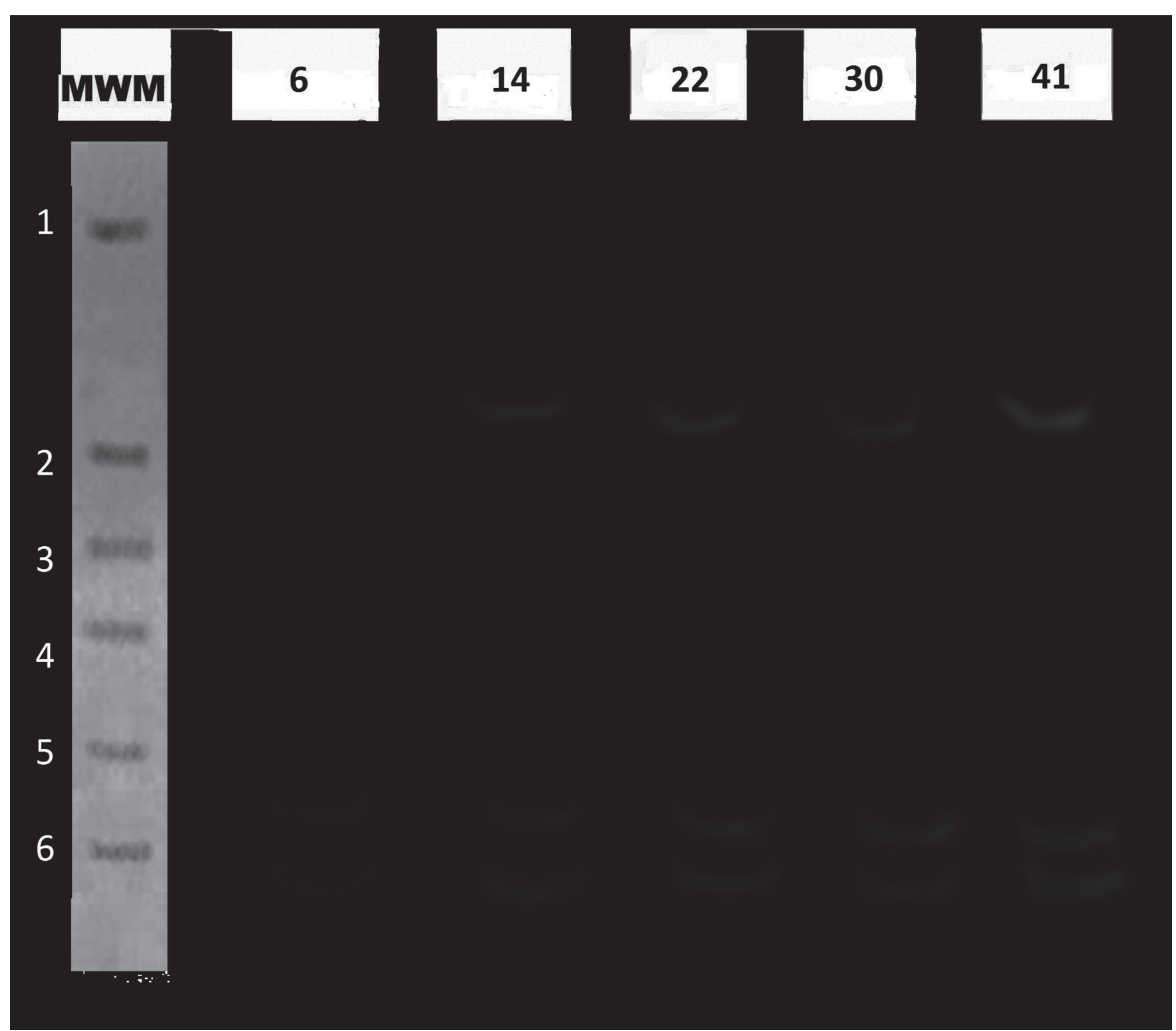

Fig. 4. Zymograms of digestive proteases during ontogeny of Parachromis dovii larvae a SDS-PAGE for alkaline proteases. MWM: Marker of molecular weights, 1) phosphorylase b $(97 \mathrm{kDa}), 2)$ serum bovine albumin $(66 \mathrm{kDa}), 3)$ egg albumin (45 $\mathrm{kDa})$, 4) carbonic anhydrase $(29 \mathrm{kDa}), 5)$ trypsinogen $(24 \mathrm{kDa})$, and 6) soybean trypsin inhibitor $(20 \mathrm{kDa})$.

Further, the pepsin-like activity is also a good indicator of the transition from larvae to juvenile as it has been reported for perch, Sander lucioperca (Linnaeus), common pandora, Pagellus erythrinus (Linnaeus) (Suzer et al., 2006; Hamza et al., 2007) and freshwater species as M. urouphthalmus (López-Ramírez et al., 2011), P. splendida (Treviño et al., 2011; Uscanga-Martínez et al., 2011) and O. niloticus (Uscanga-Martínez et al., 2010). The difference in the time of detection of pepsin activity and gastric glands may be due to the species variation. Recent study has demonstrated daily rhythms of digestive enzyme activity in fish larvae (Mata-Sotres et al., 2016). To improve larval rearing and feeding practices, the functional development of digestive system in several species from the genus of Lutjanus has been evaluated in Pacific red snapper, Lutjanus peru (Nichols, Murphy), the appearance of the gastric glands and pyloric caeca was around 24 DAH (Peña et al., 2017), and pepsin secretion was detected around $25 \mathrm{DAH}$ (Moguel-Hernandez et al., 2014).

The result from the current study together with previous published data suggests that digestive enzymes of fish larvae are presented at a low level before the onset exogenous feeding and their activities increase to a high level during exogenous feeding. In contrast to a taxonomically similar species onset points of trypsin as M. urophthalmus (López-Ramirez et al., 2011) and A. trimaculatus (Toledo-Solís et al., 2015), amylase and lipase in pompano, Trachinotus ova- tus (Linnaeus), are triggered by internal mechanisms, rather than dietary stimulation; for this reason, the fluctuations in specific enzyme activities covered the period of morphological differentiation in the digestive tract and the development of digestive glands (Ma et al., 2015). According to this study, gastric glands were first observed on $14 \mathrm{DPH}$, but the pepsin activity of crimson snapper was not detected until $17 \mathrm{DPH}$. Such development may cause by the feeds shifting from rotifers to Artemia nauplii.

The alkaline proteolytic activity for $P$. dovii larvae shows a similar trend as that found with other freshwater species, specially related to the increasing in digestive enzyme activities during the first 10 to $15 \mathrm{DAH}$. This is the result of intestine digestion due to not only the secretion of different pancreatic proteases to the lumen (trypsin, chymotrypsin and carboxypeptidases) but also to the action of digestive enzymes from intestinal wall (aminopeptidases). The alkaline proteolytic activity observed from 6 DAH $(9.49 \mathrm{~mm}$, $168 \mathrm{DD}, 0.056 \mathrm{~mm} .{ }^{\circ} \mathrm{C}$.days) acts after protein hydrolysis by stomach acid proteases; agreeing with pattern described for M. urouphthalmus (López-Ramírez et al., 2011). Similarly, with Solea senegalensis Kaup, Atractosteus tristoechus (Bloch, Schneider), Labeo catla (Hamilton), Hypophthalmichthys molitrix (Valenciennes) and Sciaenops ocellatus (Linnaeus) larvae, the alkaline digestive enzyme activity was detected between 2 and $18 \mathrm{DAH}$, followed by a reduction (Ribeiro et al., 1999; Comabella et al., 2006; Kumar et 
al., 2007; Lazo et al., 2007; Khosravi Bakhtiarvandi, Abedian-Kenari, 2015; Xiao-Qiang et al., 2017).

The reduction of the specific activity levels for most of the digestive enzymes tested at the transition from larvae to juvenile (between 22 and $30 \mathrm{DAH}, 20.83 \mathrm{~mm}, 550 \mathrm{DD}$, $0.057 \mathrm{~mm} .{ }^{\circ} \mathrm{C}$.days and $23.42 \mathrm{~mm}, 810 \mathrm{DD}, 0.028 \mathrm{~mm} .{ }^{\circ} \mathrm{C}$. days, respectively) has been reported for other species and it seems to be related to physiological changes that occur during larval development, such as the increment of other soluble proteins in the extracts, the appearance of other hormones or enzymes, or may be genetically programmed (Zambonino-Infante, Cahu, 2001; Lazo et al., 2007). It is well known that digestive enzymes play great roles in the catabolism of yolk, the processes of energy metabolism and growth regulation during embryonic developmental stages in fishes (Zhao et al., 2016). Accordingly, enzymes represent important links between the nutrients and the basal metabolism and growth (Santos et al., 2016). Furthermore, some specific enzymes correlate closely with gamete quality (Jia et al., 2013).

Larvae of $P$. dovii have a high capability to digest protein from different sources, because of the presence of trypsin, chymotrypsin, leucine aminopeptidase and carboxypeptidase A. These enzymes are capable to hydrolyze peptide bonds (functioning as endopeptidases or exopeptidases), releasing peptides and amino acids, which, in turn, are easily absorbed by the larvae to fulfill its requirements and complete the metamorphosis to juvenile (e.g. scale formation, spine growth). The latter is favored by the early appearance of a functional stomach (Valverde-Chavarría et al., 2013) with pepsin-like activity since $6 \mathrm{DAH}(9.49 \mathrm{~mm}, 168 \mathrm{DD}, 0.056$ $\mathrm{mm} .{ }^{\circ} \mathrm{C}$.days).

Trypsin specific activity reached its maximum during first $14 \mathrm{DAH}\left(15.10 \mathrm{~mm}, 364 \mathrm{DD}, 0.041 \mathrm{~mm} .{ }^{\circ} \mathrm{C}\right.$.days), decreasing days after, while the chymotrypsin specific activity was low at $6 \mathrm{DAH}\left(9.49 \mathrm{~mm}, 168 \mathrm{DD}, 0.056 \mathrm{~mm} .{ }^{\circ} \mathrm{C}\right.$.days $)$ and gradually increased to reach its maximum at $41 \mathrm{DAH}$ (27.66 mm, $1189 \mathrm{DD}, 0.023 \mathrm{~mm} .{ }^{\circ} \mathrm{C}$.days). Fluctuations in the specific activity of trypsin and chymotrypsin have also been reported in larvae of other species such as $S$. ocellatus (Lazo et al., 2007), S. hasta (Nazemroaya et al., 2015), E. coioides (Guo et al., 2016), L. erythopterus (Cui et al., 2017) and A. sapidissima (Xiao-Qiang et al., 2017), which has been attributed to genetically programmed changes and variations in the natural food organisms (Zambonino-Infante, Cahu, 2001). Furthermore, the different interactions between alkaline enzymes such as trypsin and chymotrypsin may be considered good indicators of nutritional quality of larvae stages (Cara et al., 2003). The lack of trypsin in the first few days may be compensated by pinocytosis until the digestive tract becomes fully functional to digest protein in lumen itself (Sharma et al., 2016).

The activity of leucine aminopeptidase and of carboxypeptidase A happens in the enterocyte microvilli (parietal digestion), being of relevance in the protein digestion to make available amino acids from the amino and carboxyl protein group. In this context, the aminopeptidase has been used as an indicator of digestive tract maturity. In European seabass, Dicentrarchus labrax (Linnaeus) and O. niloticus larvae, aminopeptidase was detected in the intestine just before first feeding, increasing its activity from 3 DAH when the appearance of mouth opening happens (Zambonino-Infante, Cahu, 1994; Tengjaroenkul et al., 2002). Similarly, yellowtail flounder, Myzopsetta ferrugineus (Storer), winter flounder, Pseudopleuronectes americanus (Walbaum), M. urophthalmus showed aminopeptidase activity during embryonic period and hatching (Baglole et al., 1998; LópezRamírez et al., 2011), R. kutum (Khosravi Bakhtiarvandi, Abedian-Kenari, 2015) and A. sapidissima (Xiao-Qiang et al., 2017) increased until 7-18 DAH.

The increment of alkaline phosphatases activity reflects the enterocytes brush border development, which in turn, it is associated with the diminishing of cytosolic enzymes, agreeing with $S$. senegalensis larvae (Ribeiro et al., 2002). The latter is an indication of the digestive system maturation (which it is faster than skeletal system development) and, from the digestive physiology viewpoint, of the transition from larvae to juvenile stage (Balon, 1984; Kendall et al., 1984). The acid phosphatase was also present from $6 \mathrm{DAH}$ (9.49 mm, $168 \mathrm{DD}, 0.056 \mathrm{~mm} .{ }^{\circ} \mathrm{C}$.days), with a maximal activity at $14 \mathrm{DAH}\left(15.10 \mathrm{~mm}, 364 \mathrm{DD}, 0.041 \mathrm{~mm} .{ }^{\circ} \mathrm{C}\right.$.days), which may indicate that not only the enterocytes are mature but also that nutrient absorption processes are more efficient. Similar trends for activity increments and microvilli development were found with D. labrax, S. aurata, R. kutum and A. sapidissima (Zambonino-Infante, Cahu, 1994; Moyano et al., 1996; KhosraviBakhtiarvandi, Abedian-Kenari,2015; Xiao-Qiang et al., 2017). The increment in activity of these enzymes is not only correlated to enterocyte maturation but also to genetic modulation; however, it may also vary due to composition of feed used (Zambonino-Infante, Cahu, 1994; 2001; Gawlicka et al., 1995; Hakim et al., 2007).

Lipase study during larvae ontogeny has great importance because they are related to dietary lipids utilization (López-Lópezet al., 2008). As larvae can't synthesize de novo n-6 linoleic and linolenic n-3 fatty acids series, they must be added in diets taking into consideration that type and concentration of required polyunsaturated fatty acids (PUFA) vary between fish species and digestive larvae capability. In this context, PUFA's play a key role at cellular membrane, increasing its fluidity, flexibility and permeability, reason to incorporate them in the diets. Their utilization by the fish is modulated by esterases, phospholipases and true lipases (Evans et al., 1998). Parachromis dovii larvae showed high lipases activity since 14 DAH $(15.10 \mathrm{~mm}, 364 \mathrm{DD}, 0.041$ $\mathrm{mm} .{ }^{\circ} \mathrm{C}$.days), reaching the highest activity at $41 \mathrm{DAH}$ (at juvenile stage, $27.66 \mathrm{~mm}, 1189 \mathrm{DD}, 0.023 \mathrm{~mm} .{ }^{\circ} \mathrm{C}$.days) agreeing with yellowtail kingfish, Seriola lalandi Valenciennes, L. catla,R. kutum, E. coloides, L. erythropterus, C. chitala, A. sapidissima and Barbel chub, Squaliobarbus curriculus (Chen et al., 2006; Kumar et al., 2007; Khosravi Bakhtiarvandi, Abedian-Kenari, 2015; Guo et al., 2016; Cui et al., 
2017; Mitra et al., 2017; Xiao-Qiang et al., 2017; Shen et al., 2018).

The $\alpha$-amylase activity in $P$. dovii was founded from 6 DAH $\left(9.49 \mathrm{~mm}, 168 \mathrm{DD}, 0.056 \mathrm{~mm} .{ }^{\circ} \mathrm{C}\right.$.days $)$, fluctuating with low levels, during ontogeny as found for $O$. niloticus (Tengjaroenkul et al., 2002). This finding differs from other fish species, especially marine, such as white seabream, $D i$ plodus sargus (Linnaeus), D. labrax, R. kutum, E. coloides, L. erythropterus, C. chitala, A. sapidissima and S. curriculus (Cara et al., 2003; Cahu et al., 2004; Khosravi Bakhtiarvandi, Abedian-Kenari, 2015; Guo et al., 2016; Cui et al., 2017; Mitra et al., 2017; Xiao-Qiang et al., 2017; Shen et al., 2018), in which amylase activity decreased with fish age. In monogastric fish, amylase activity has low impact but in agastric ones it is relevant in carbohydrate digestion, e.g. in L. catla (Kumar et al., 2007), an herbivorous species. In $P$. dovii, the amylase activity presented should improve the use of carbohydrates from the glycogen hydrolysis from its prey during larvae-juvenile transition.

The number of digestive enzyme isoforms expressed on the different species it is related with feeding habits of the species, so when counting with six bands of proteases activities, $P$. dovii may be considered a species of omnivore habits similar to M. urophthalmus (López-Ramirez et al., 2011); besides, this type and number of isoforms have been detected in other fish species such as Senegal sole, Solea senegalensis (Kaup) with seven types of bands (Sáenz-de Rodrigáñez et al., 2005), while in carnivore species, the number of bands is low as Atlantic bluefin tuna, Thunnus thynnus (Linnaeus) with three isoforms (Essed et al., 2002), spotted sand bass, Paralabrax maculatofasciatus (Steindachner) with two isoforms (Alvarez-González et al., 2010), common snook, Centropomus undecimalis (Bloch) with two isoforms (Jimenez-Martínez et al., 2012) and C. trimaculatus with six bands of proteases activities (Toledo-Solís et al., 2015).

According to the results of this study, $P$. dovii larvae have a complete digestive enzyme activity from 6 DAH (first feeding, $9.49 \mathrm{~mm}, 168 \mathrm{DD}, 0.056 \mathrm{~mm} .{ }^{\circ} \mathrm{C}$.days), that maximize after $14 \mathrm{DAH}\left(15.10 \mathrm{~mm}, 364 \mathrm{DD}, 0.041 \mathrm{~mm} .{ }^{\circ} \mathrm{C}\right.$.days $)$ when larvae were fed with live food, which indicates that the exogenous feeding with a formulated diet can be started by this time. From the nutritional point of view, it is needed to search for the nutritional requirements of the larval stage and to evaluate the in vitro digestibility of diets and ingredients for this specie.

In conclusion the digestive enzymes, alkaline phosphatase, amylase, lipase, chymotrypsin, and trypsin in our study were present before the onset of exogenous feeding in $P$. dovii larvae. The relatively high specific activity of chymotrypsin and trypsin facilitate digestion of protein at an early stage. The pattern of primary digestive enzyme activity indicates early functional development of the digestive system. This study on digestive enzyme patterns will provide valuable information on the nutritional requirements of larvae and help establish feeding protocols for optimizing larval mass-rearing production.

\section{Acknowledgments}

This research was supported by the projects SIA 0021-07 PS “Tecnología Acuicultural” and SIA 0315-10 "Desarrollo de una dieta inerte para larvas del guapote lagunero Parachromis dovii (Pisces Cichlidae) formulada de acuerdo con su capacidad digestiva y requerimientos proteicos" of the Escuela de Ciencias Biológicas, Universidad Nacional; and by the research project: Programa de Fomento a la Investigación "Fisiología digestiva del guapote lagunero (Parachromis dovii)", UJAT-2013-IB-29.

\section{References}

Alvarez-González CA, Moyano-López FJ, Civera-Cerecedo R, Carrasco-Chávez V, Ortíz-Galindo JL, Nolasco-Soria H, Tovar-Ramírez D, Dumas S. Development of digestive enzyme activity in larvae of spotted sand bass Paralabrax maculatofasciatus II: electrophoretic analysis. Fish Physiol Biochem [serial on the Internet]. 2010; 36(1):29-37. Available from: https://doi.org/10.1007/s10695-008-9276-4

Anson ML. The estimation of pepsin, trypsin, papain, and cathepsin with hemoglobin. J Gen Physiol [serial on the Internet]. 1938; 22(1):79-89. Available from:https://www.ncbi.nlm.nih.gov/ pmc/articles/PMC2213732/

Baglole CJ, Goff GP, Wright GM. Distribution and ontogeny of digestive enzymes in larval yellowtail and winter flounder. $\mathrm{J}$ Fish Biol [serial on the Internet]. 1998; 53(4):767-84. Available from: https://doi.org/10.1111/j.1095-8649.1998.tb01831.x

Balon EK. Reflections on some decisive events in the early life of fishes.Trans Am Fish Soc [serial on the Internet]. 1984; 113(2):178-85. Available from: https://doi.org/10.1577/15488659(1984)113<178:ROSDEI $>2.0$. CO;2

Barrera A RE, Paz G CE. Control de alevines de tilapia (Oreochromis niloticus) (Perciforme: Cichlidae) usando guapote lagunero (Parachromis dovii) (Perciforme: Cichlidae) en los estanques de la Universidad Earth. [PhD thesis] Guácimo, Costa Rica: Universidad Earth; 2006.

Bergmeyer HU. Phosphatases. In: Bergmeyer HU, editor. Methods of enzymatic analysis. $2^{\text {nd }}$ edition, Vol 2. New York: Academic Press: 1974.

Bradford MM. A rapid and sensitive method for the quantization of microgram quantities of protein utilizing the principle of protein-dye binding. Anal Biochem [serial on the Internet]. 1976; 72(1-2):248-25. Available from: https://doi. org/10.1016/0003-2697(76)90527-3

Cahu C, Rønnestad I, Grangier V, Zambonino-Infante JL. Expression and activities of pancreatic enzymes in developing sea bass larvae (Dicentrarchus labrax) in relation to intact and hydrolyzed dietary protein; involvement of cholecystokinin. Aquaculture [serial on the Internet]. 2004; 238(1-4):295-308. Available from: https://doi.org/10.1016/j. aquaculture.2004.04.013

Cara JB, Moyano FJ, Cárdenas S, Fernández-Díaz C, Yúfera M. Assessment of digestive enzyme activities during larval development of white bream (Diplodus sargus). J Fish Biol [serial on the Internet]. 2003; 63(1):48-58. Available from: https://doi.org/10.1046/j.1095-8649.2003.00120.x

Chen BN, Qin JG, Kumar MS, Hutchinson WG, Clarke SM. Ontogenetic development of digestive enzymes in yellowtail kingfish Seriola lalandi larvae. Aquaculture [serial on the 
Internet]. 2006; 260(1-4):264-71. Available from: https://doi. org/10.1016/j.aquaculture.2006.06.021

Chong AS, Hashim R, Lee LC, Ali AB. Characterization of protease activity in developing discus Symphysodon aequifasciatus larva. Aquac Res [serial on the Internet]. 2002; 33(9):663-72. Available from: https://doi.org/10.1046/j.13652109.2002.00702.x

Comabella Y, Mendoza R, Aguilera C, Carrillo O, Hurtado A, García-Galano T. Digestive enzyme activity during early larval development of the cuban gar Atractosteus tristoechus. Fish Physiol Biochem [serial on the Internet]. 2006; 32:147-57. Available from: https://doi.org/10.1007/s10695-006-0007-4

Cui K, Cheng D, Ma Z, Qin JG, Jiang S, Sun D, Ma S. Ontogenetic development of digestive enzymes in larval and juvenile crimson snapper Lutjanus erythopterus (Bloch 1790). Aquac Res [serial on the Internet].2017; 48(8):4533-44. Available from: https://doi.org/10.1111/are.13278

Del Mar EG, Largman C, Brodrick J, Geokas M. A sensitive new substrate for chymotrypsin. Anal Biochem [serial on the Internet]. 1979; 99(2):316-20. Available from: https://doi. org/10.1016/S0003-2697(79)80013-5

Erlanger BF, Kokowsky N, Cohen W. The preparation and properties of two new chromogenic substrates of trypsin. Arch Biochem Biophys [serial on the Internet]. 1961; 95(2):271-78. Available from: https://doi.org/10.1016/0003-9861(61)90145-X

Essed Z, Fernández I, Alarcón FJ, Moyano FJ. Caracterización de la actividad proteasa digestiva de atún rojo Thunnus thynnus (Linnaeus, 1758). Bol Inst Esp Ocean. 2002; 18(1-4):99-107.

Evans RP, Parrish CC, Zhu P, Brown JA, Davis PJ. Changes in phospholipase $\mathrm{A}_{2}$ activity and lipid content during early development of Atlantic halibut (Hippoglossus hippoglossus). Mar Biol [serial on the Internet]. 1998; 130(3):369-76. Available from: https://doi.org/10.1007/s002270050257

Folk JE, Schirmer EW. The porcine pancreatic carboxypeptidase A system. I. Three forms of the active enzyme. J Biol Chem. 1963; 238(12):3884-94.

García-Carreño FL, Dimes LE, Haard NF. Substrate-gel electrophoresis for composition and molecular weight of proteinases or proteinaceous proteinase inhibitors. Anal Biochem [serial on the Internet]. 1993; 214(1):65-69. Available from: https://doi.org/10.1006/abio.1993.1457

Gawlicka A, Teh SJ, Hung SSO, Hinton DE, de la Noue J. Histological and histochemical changes in the digestive tract of white sturgeon larvae during ontogeny. Fish Physiol Biochem [serial on the Internet]. 1995; 14(5):357-71. Available from: https://doi.org/10.1007/BF00003374

Guerrera MC, De Pasquale F, Muglia U, Caruso G. Digestive enzymatic activity during ontogenetic development in Zebrafish (Danio rerio). J Exp Zool [serial on the Internet]. 2015; 324(8):699-706. Available from: https://doi.org/10.1002/ jez.b. 22658

Guo H, Li J, Ma Z, Zhang J, Zhen P, Cheng D. Ontogenetic development of digestive enzymes in orange-spotted grouper (Epinephelus coloides, Hamilton, 1822) larvae. Isr J Aquac [serial on the Internet]. 2016; 68:1-12. Available from: http:// hdl.handle.net/10524/54962

Hakim Y, Rowland SJ, Guy JA, Mifsud C, Uni Z, Harpaz S. Effects of genetic strain and holding facility on the characteristics of alkaline phosphatase and brush border enzymes in silver perch (Bidyanus bidyanus). Aquac Res [serial on the Internet]. 2007; 38:361-72. Available from: https://doi.org/10.1111/j.13652109.2007.01674.x
Hamza N, Mhetli M, Kestemont P. Effects of weaning age and diets on ontogeny of digestive activities and structures of pikeperch (Sander lucioperca) larvae. Fish Physiol Biochem [serial on the Internet]. 2007; 33(2):121-33. Available from: https://doi. org/10.1007/s10695-006-9123-4

Hazel JR, Prosser CL. Molecular mechanisms of temperature compensation in poikilotherms. Physiol Rev [serial on the Internet]. 1974; 54(3):620-77. Available from: https://doi. org/10.1152/physrev.1974.54.3.620

Hernández R. Crecimiento de Cichlasoma dovii (Günther, 1864) (PISCES: Cichlidae) en jaulas a diferentes densidades, alimentado con una dieta formulada. [monograph]. Heredia, Costa Rica: Escuela de Ciencias Biológicas, Universidad Nacional; 1992.

Igbokwe EC, Downe AER. Electrophoretic and histochemical comparison of three strains of Aedes aegypti. Comp Biochem Physiol B [serial on the Internet]. 1978; 60(2):131-36. Available from: https://doi.org/10.1016/0305-0491(78)90117-7

Jia YD, Meng Z, Liu XF, Gao CR, Niu HX, Lei JL. Activities of phosphatase in eggs and ovarian fluids and its correlation with the fertilization rate during the reproductive cycle of turbot (Scophthalmus maximus). Haiyang Yu Huzhao. 2013; 44(6):1530-35.

Jimenez-Martínez LD, Álvarez-González CA, Tovar-Ramírez D, Gaxiola G, Sánchez-ZamoraA, Moyano FJ,AlarcónFJ, MárquezCouturier G, Gisbert E, Contreras-Sánchez WM, Perales-García $\mathrm{N}$, Arias-Rodríguez L, Indy JR, Páramo-Delgadillo S, PalominoAlbarrán IG. Digestive enzyme activities during early ontogeny in Common snook (Centropomus undecimalis). Fish Physiol Biochem [serial on the Internet]. 2012; 38(2):441-54. Available from: https://doi.org/10.1007/s10695-011-9525-9

Kendall AW, Ahlstrom EH, Moser HG. Early life history stages of fishes and their characters. In: Moser HG, Richards WJ, Cohen DM, Fahay MP, Kendall AW Jr., Richardson SL, editors. Ontogeny and systematics of fishes. Lawrense: Allen Press; 1984. p.11-24.

Khosravi-Bakhtiarvandi N, Abedian-Kenari AM. Changes of digestive enzymes activity in Caspian Kutum (Rutilus frisii kutum) during larval developmental stages. Iran J Fish Sci [serial on the Internet]. 2015; 14(1):158-75. Available from: http://aquaticcommons.org/id/eprint/22764

Kolkovski S. Digestive enzymes in fish larvae and juvenilesimplications and applications to formulated diets. Aquaculture [serial on the Internet]. 2001; 200(1-2):181-201. Available from: https://doi.org/10.1016/S0044-8486(01)00700-1

Kumar S, García-Carreño FI, Chakrabarti R, Toro MAN, CordovaMurueta JD. Digestive proteases of three carps Catla catla, Labeo rohita and Hypophthalmichthys molitrix: partial characterization and protein hydrolysis efficiency. Aquac Nutr [serial on the Internet]. 2007; 13(5):381-88. Available from: https://doi.org/10.1111/j.1365-2095.2007.00488.x

Laemmli UK. Cleavage of structural proteins during the assembly of the head of bacteriophage T4. Nature [serial on the Internet]. 1970; 227:680-85. Available from: https://doi. org/10.1038/227680a0

Lazo JP, Mendoza R, Holt GJ, Aguilera C, Arnold CR. Characterization of digestive enzymes during larval development of red drum (Sciaenops ocellatus). Aquaculture [serial on the Internet]. 2007; 265(1-4):194-205. Available from: https://doi.org/10.1016/j.aquaculture.2007.01.043

López-López S, Nolasco H, Vega-Villasante F. Characterization of digestive gland esterase-lipase activity of juvenile redclaw crayfish Cherax quadricarinatus. Comp Biochem Physiol B 
Digestive enzymatic ontogeny of Parachromis dovii

[serial on the Internet]. 2008; 135(2):337-47. Available from: https://doi.org/10.1016/S1096-4959(03)00087-3

López-Ramírez G, Cuenca-Soria CA, Alvarez-González CA, TovarRamírez D, Ortiz-Galindo JL, Perales-García N, MárquezCouturier G, Arias-Rodríguez L, Indy JR, Contreras-Sánchez WM, Gisbert E, Moyano FJ. Development of digestive enzymes in larvae of Mayan cichlid Cichlasoma urophthalmus. Fish Physiol Biochem [serial on the Internet]. 2011; 37(1):197-208. Available from: https://doi.org/10.1007/s10695-010-9431-6

Luna-Figueroa J, Figueroa-Torres J. Reproducción y crecimiento en cautiverio de la mojarra criolla Cichlasoma istlanum (Pisces: Cichlidae). Rev AquaTIC. 2000; 10:1-13.

Ma Z, Zheng P, Guo H, Zhang N, Wang L, Jiang S, Qin JG, Zhang D. Effect of weaning time on the performance of Trachinotus ovatus (Linnaeus 1758) larvae. Aquac Nutr [serial on the Internet]. 2015; 21(5):670-78. Available from: https://doi. org/10.1111/anu.12183

Maroux S, Louvard D, Barath J. The aminopeptidase from hogintestinal brush border. Acta Biochem Biophysiol [serial on the Internet]. 1973; 321(1):282-95. Available from: https://doi. org/10.1016/0005-2744(73)90083-1

Mata-Sotres JA, Moyano FJ, Martínez-Rodríguez G, Yúfera M. Daily rhythms of digestive enzyme activity and gene expression in gilthead seabream (Sparus aurata) during ontogeny. Comp Biochem Physiol A [serial on the Internet]. 2016; 197:43-51. Available from:https://doi.org/10.1016/j.cbpa.2016.03.010

Mitra A, Mukhopadhayay PK, Homechaudhuri S. Profile of digestive enzymes activity during early development of Featherback Chitala chitala (Hamilton, 1822). Procc Zool Soc [serial on the Internet]. 2017; 70(2):141-49. Available from: https://doi.org/10.1007/s12595-016-0169-8

Moguel-Hérnandez I, Peña R, Nolasco-Soria H, Duma S, ZavalaLeal I. Development of digestive enzyme activity in spotted rose snapper, Lutjanus guttatus (Steindachner, 1869) larvae. Fish Physiol Biochem [serial on the Internet]. 2014; 40(3):839-48. Available from: https://doi.org/10.1007/s10695-013-9890-7

Moyano FJ. Bioquímica digestiva en especies acuicultivadas: aplicaciones en nutrición. In: Cruz SE, Ricque MR, Tapia SM, Nieto LMG, Villarreal CDA, Puello CAC, García OA, editors. Avances en Nutrición Acuícola VIII. Nuevo León, Monterrey: VIII Symposium International de Nutrición Acuícola, Universidad Autónoma de Nuevo León; 2006. p.396-409.

Moyano FJ, Díaz M, Alarcón FJ, Sarasquete MC. Characterization of digestive enzyme activity during larval development of gilthead seabream (Sparus aurata). Fish Physiol Biochem [serial on the Internet]. 1996; 15(2):121-30. Available from: https://doi.org/10.1007/BF01875591

Nazemroaya S, Yazdanparast R, Nematollahi MA, Farahmand H, Mirzadeh Q. Ontogenetic development of digestive enzymes in Sobaity sea bream Sparidentex hasta larvae under culture condition. Aquaculture [serial on the Internet]. 2015; 448(1):545-51. Available from: https://doi.org/10.1016/j. aquaculture.2015.06.038

Nonell JG, Rojas JU. Growth and feed utilization of wolf cichlid (Cichlasoma dovii) larvae fed Artemia nauplii. Rev Biol Trop. 1995; 43(1-3):277-82.

Peña R, Dumas S, Contreras-Olguin M. Organogenesis of the digestive system in Pacific red snapper (Lutjanus peru) larvae. Aquac Res [serial on the Internet]. 2017; 48(4):1561-75. Available from: https://doi.org/10.1111/are.12991

Pujante IM, Díaz-López M, Mancera JM, Moyano FJ. Characterization of digestive enzymes protease and alpha- amylase activities in the thick-lipped grey mullet (Chelon labrosus, Risso 1827). Aquac Res [serial on the Internet]. 2017; 48(2):367-76. Available from:https://doi.org/10.1111/ are. 13038

Quirós-Orlich JR, Valverde Chavarría S, Ulloa Rojas JB. The proteolytic digestive activity and grow during ontogeny of Parachromis dovii larvae (Pisces: Cichlidae) using two feeding protocols. Fish Physiol Biochem [serial on the Internet]. 2014; 40(4):1253-61. Available from: https://doi.org/10.1007/ s10695-014-9920-0

Ribeiro L, Zambonino-Infante JL, Cahu C, Dinis MT. Development of digestive enzymes in larvae of Solea senegalensis Kaup, 1858. Aquaculture [serial on the Internet]. 1999; 170(14):465-73. Available from: https://doi.org/10.1016/S00448486(99)00180-5

Ribeiro L, Zambonino-Infante JL, Cahu C, Dinis MT. Digestive enzymes profile of Solea senegalensis post larvae fed Artemia and a compound diet. Fish Physiol Biochem [serial on the Internet]. 2002; 27(1-2):61-69. Available from: https://doi. org/10.1023/B:FISH.0000021817.98363.47

Robyt JF, Whelan WJ. The a-amylases. In: Radley JA, editor. Starch and its derivates. 4th edition. London: Chapman and Hall; 1968. p.430-476.

Sáenz-de Rodrigáñez M, de Oña C, Alarcón FJ, Martínez MI, Díaz M, Moyano FJ. Crecimiento y enzimas digestivas de larvas de Solea senegalensis Kaup, 1858 alimentadas con piensos comerciales. Bol Inst Español Ocean. 2005; 21(1-4):105-13.

Santos JF, Soares KLS, Assis CRD, Guerra CAM, Lemos D, Carvalho Júnior LB, Bezerra RS. Digestive enzyme activity in the intestine of Nile tilapia (Oreochromis niloticus L.) under pond and cage farming systems. Fish Physiol Biochem [serial on the Internet]. 2016; 42(5):1259-74. Available from:https:// doi.org/10.1007/s10695-016-0215-5

Sharma P, Akhtar MS, Singh AK, Das P, Sarma D. Histomorphological changes in digestive tract of golden mahseer (Tor putitora) during different developmental stages. Fish Physiol Biochem [serial on the Internet]. 2016; 42(6):168198. Available from:https://doi.org/10.1007/s10695-016-0249-8

Sharpe PJH, DeMichele DW. Reaction kinetics of poikilotherm development. J Theor Biol [serial on the Internet]. 1977; 64(4):649-70. Available from: https://doi.org/10.1016/00225193(77)90265-X

Shen F, Li C, Teng T, Chen Y, Guo J, Zhu C, Ling Q. Ontogenetic development of digestive tract and digestive enzymatic activities in Squaliobarbus curriculus larvae. Aquac Res [serial on the Internet]. 2018; 49(9):3158-66. Available from: https:// doi.org/10.1111/are.13779

Song Z, Wang J, Qiao H, Li P, Zhang L, Xia B. Ontogenetic changes in digestive enzyme activities and the amino acid profile of starry flounder Platichthys stellatus. Chinese J Ocean Limnol [serial on the Internet]. 2016; 34(5):1013-24. Available from: https://doi.org/10.1007/s00343-016-5031-3

Suzer C, Saka S, Firat K. Effects of illumination on early life development and digestive enzyme activities in common Pandora Pagellus erythrinus L. larvae. Aquaculture [serial on the Internet]. 2006; 260(1-4):86-93. Available from:https://doi. org/10.1016/j.aquaculture.2006.06.025

Tengjaroenkul B, Smith BJ, Smith SA, Chatreewongsin U. Ontogenic development of the intestinal enzymes of cultured Nile tilapia, (Oreochromis niloticus L). Aquaculture [serial on the Internet]. 2002; 211(1-4):241-51. Available from: https:// doi.org/10.1016/S0044-8486(01)00888-2 
Toledo-Solís FJ, Uscanga-Martínez A, Guerrero-Zárate R, Márquez-Couturier G, Martínez-García R, Camarillo-Coop S, Perales-García N, Rodríguez-Valencia W, Gómez-Gómez MA, Álvarez-González CA. Changes on digestive enzymes during initial ontogeny in the three-spot cichlid Cichlasoma trimaculatum. Fish Physiol Biochem [serial on the Internet]. 2015; 41(1):267-79. Available from:https://doi.org/10.1007/ s10695-014-0023-8

Tong X, Yang X, Bao C, Tang X, Wang J, Zhou Y, Tang M. Ontogeny of the digestive enzymes, thyroid hormones and cortisol in developing embryos and yolk-sac larvae of turbot (Scophthalmus maximus L.). Aquaculture [serial on the Internet]. 2017; 479:704-11. Available from: https://doi. org/10.1016/j.aquaculture.2017.07.004

Treviño L, Álvarez-González CA, Perales-García N, Arévalo-Galán L, Uscanga-Martínez A, Márquez-Couturier G, Fernández I, Gisbert E. A histological study of the organogenesis of the digestive system in bay snook Petenia splendida Günter, 1862 from hatching to the juvenile stage. J Applied Ichthyol [serial on the Internet]. 2011; 27(1):73-82. Available from: https://doi. org/10.1111/j.1439-0426.2010.01608.x

Uscanga-Martínez A, Moyano FJ, Álvarez-González CA. Assessment of enzymatic efficiency on protein digestion in the tilapia Oreochromis niloticus. Fish Physiol Biochem [serial on the Internet]. 2010; 36(4):1079-85. Available from: https://doi. org/10.1007/s10695-010-9385-8

Uscanga-Martínez A, Perales-García N, Álvarez-González CA, Moyano FJ, Tovar-Ramírez D, Gisbert E, Márquez-Couturier G, Contreras-Sánchez W, Arias-Rodríguez L, Indy JR. Changes in digestive enzyme activity during initial ontogeny of bay snook Petenia splendida. Fish Physiol Biochem [serial on the Internet]. 2011; 37(3):667-80. Available from: https:// doi.org/10.1007/s10695-011-9467-2

Valverde-Chavarría S, Álvarez-González CA, Ulloa-Rojas JB, Frías-Quintana CA, Guerrero-Zárate R, Quirós-Orlich JR, Brais-Medina M, Calvo-Elizondo E, Alvarado-Guzmán L. Ontogenia del sistema digestivo del guapote lagunero Parachromis dovii durante el periodo larval y selección de ingredientes para su alimentación. In: Cruz-Suárez LE, RicqueMarie D, Tapia-Salazar M, Nieto-López MG, VillarrealCavazos DA, Gamboa-Delgado J, Álvarez-González CA, editors. Contribuciones recientes en alimentación y nutrición acuícola. Monterrey, Nuevo León, México: XII Simposium Internacional de Nutrición Acuícola, Universidad Autónoma de Nuevo León; 2013. p.318-53.
Versaw WK, Cuppett SL, Winters DD, Williams LE. An improved colorimetric assay for bacterial lipase in nonfat dry milk. J Food Sci [serial on the Internet]. 1989; 54(6):1557-58. Available from:https://doi.org/10.1111/j.1365-2621.1989.tb05159.x

Walter HE. Proteinases: methods with hemoglobin, casein and azocoll as substrates. In: Bergmeyern HU, editor. Methods of enzymatic analysis. Vol. V. Germany: Verlag Chemic Weinham; 1984. p.270-274.

Xiao-Qiang G, Liu ZF, Guan CT, Huang B, Lei JL, Li J, Guo ZL, Wang YH, Hong L. Developmental changes in digestive enzyme activity in American shad, Alosa sapidissima, during early ontogeny. Fish Physiol Biochem [serial on the Internet]. 2017; 43(2):397-409.

Zambonino-Infante JL, Cahu C. Development and response to a diet change of some digestive enzymes in sea bass (Dicentrarchus labrax) larvae. Fish Physiol Biochem [serial on the Internet]. 1994; 12(5):399-408. Available from: https://doi.org/10.1007/ BF00004304

Zambonino-Infante JL, Cahu CL. Ontogeny of the gastrointestinal tract of marine fish larvae. Comp Biochem Physiol C [serial on the Internet]. 2001; 130(4):477-87. Available from:https://doi. org/10.1016/S1532-0456(01)00274-5

Zambonino-Infante JL, Cahu CL. Dietary modulation of some digestive enzymes and metabolic processes in developing marine fish: applications to diet formulation. Aquaculture [serial on the Internet]. 2007; 268(1-4):98-105. Available from: https://doi.org/10.1016/j.aquaculture.2007.04.032

Zhao ZX, Song CY, Xie J, Ge XP, Liu B, Xia SL, Yang S, Wang Q, Zhu SH. Effects of fish meal replacement by soybean peptide on growth performance, digestive enzyme activities, and immune responses of yellow catfish Pelteobagrus fulvidraco. Fish Sci [serial on the Internet]. 2016; 82(4):665-73. Available from: https://doi.org/10.1007/s12562-016-0996-6

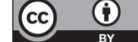

Submitted December 17, 2018 Accepted March 06, 2019 by Bernardo Baldisserotto 